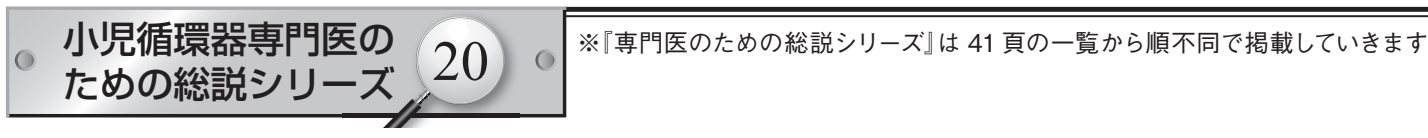

\title{
先天性心疾患診療における死生学
}

中澤 誠
一般財団法人脳神経疾患研究所附属総合南東北病院
小巟・生涯心臓疾患研究所

\section{Thanatology in the Practice of Congenital Heart Disease}

\author{
Makoto Nakazawa
}

Pediatric and Lifelong Congenital Cardiology Institute, Southern Tohoku General Hospital, Fukushima, Japan
Keywords :

thanatology, psychological sequence, Narrative-based Medicine, grief, adult congenital heart disease (ACHD)

\begin{abstract}
The practice of congenital heart disease (CHD) is a field in which we often have to face death. In the past, the death was a matter of God or Buddha, but it becomes a matter of medical science through the advance of medical technology. Accordingly, we are now required to have knowledge of thanatology in order to provide terminal care as satisfactory as possible to dying patients and families. For this purpose, we have to understand the psychological sequence of dying and death. This sequence includes shock, denial, anger, depressive feelings, and others, which are considered normal reactions to protect the mind of suffering people. Knowing their psychological status, we listen to their narrative story, which often includes personal emotions and wishes, and we give support with sympathy, accordingly. By doing this, we hope that they would pass through the painful process as comfortable as possible.

Children start understanding death in the first 1-3 grades of primary school, but their apparent reaction to death is much different from that of adults. We have to watch carefully those children who are facing dying or death and give warm and continuous support.

Now, the number of adult CHD (ACHD) patients and mortality is increasing. Their deaths are a major issue of thanatology and cause grief of parents and/or adult siblings of the ACHD patient, family, wife, and children of the ACHD patient, if any. We now have to start to prepare for this new very serious problem.
\end{abstract}

\section{要旨}

先天性心疾患 (CHD) 診療は死に直面する機会が多い分野である. 死はかつては神仏の領域であったが, 今や科学と しての医学の領域に入っており, 医療者は患者の死に際して最善の終末医療ないしケアを行うため, 死生学修得の必 要性が高じてきた. 死のケアは死にゆく本人のみならず遺族の大きな精神心理的苦痛を理解することが前提である. 本 人にも遺族にも, 死は, ショック, 死の否認, 怒りなどの「正常」の反応をもたらし, 時間をかけて容認へと向かう.わ れわれにはそれぞれの心理状態に即して, 患者の個々の「語り」に耳を傾けて, ヒトとして対応することが求められる。 小児は小学生低学年ですでに死をかなり涾く理解しているが, 死に直面する時の苦痛の表現が大人とは異なる故 に, 大人がしっかりと見守って対応する必要がある.

近年の成人 $\mathrm{CHD}$ 患者 $(\mathrm{ACHD})$ の増加は, 死生学の面からも新たに深刻な問題が起りつつあり, 今後はその対応に も腐心すべきである.

\section{はじめに}

先天性心疾患 $(\mathrm{CHD})$ 診療は, 小児〜若年成人の死に 直面する機会が最も多い分野の一つであろう。死はか つては神や仏の領域であったが, 今や科学の領域に入 りつつあり, その担い手である医療者は, 患者の死に
際して患者本人および患者家族との意思疎通を図るた めに「死生学」について知識を持つ必要が高じてきた。 しかし, 死生学はいまだ途上の学域であり学術的研究 は少なく, しかも死についての感情は個人差が大きい. したがって, その全容を述べることは筆者には到底不 可能であるが, 本稿では CHD 診療を念頭に死生学につ 
いて筆者の学び得た範囲でそのまとめを試みる。

医療のパラダイムシフト : NBM の時代へ

現在，われわれに求められている医療はいうまでも なく Evidence Based Medicine(EBM)である. 古くは権 威者が個人的な経験を根拠にした Authority Based Medicineであったが，そこには明らかな限界や誤りが あった。これを是正すべく，客観的・普遍的な医療を 行うべきとの立場から, 主として big data の統計的処 理に基づいた結果を科学的事実として医療を実践しよ うとする $\mathrm{EBM} へ と$ 移行し現在に至っている。このパラ ダイムは医療の標準化㧍よび医療の進歩に大いに貢献 したが,そこでは患者は「対象化」「客観化」されており， 医療の基本である患者をヒトとして診る視点が踈かに される傾向がある。患者は医師・医療者との人間関倸 のなかに，医療の温かみや安心を期待している。しか し, 現在の医師・医療者の忙しさや社会心理的負荷が 「温かい」医療の実践の妨げとなり，患者との人間関係 が遠のいているようにみえる，そんな時だからこそ， 患者の言葉に耳を傾け，その気持ちを汲み取ることが,

EBMによる医療の実践をさらによい医療へ引き上げ るのではなからうか. また, 治療困難な疾患, 死に至る 病気，あるいは精神心理的負担が大きい患者などでは 個々への対応が特に必要である。このため提唱された のが Narrative-based Medicine（NBM=物語に基づいた医 療)である ${ }^{1)}$. 患者の「物語」から医師・医療者は病気の 背景や人間関係を理解し, 患者に対して全人的に対応 する医療である。言い換えれば, EBMによる科学とし ての「医学」と, 人間関係の上にある「医療」の橋渡し が期待される新しいパラダイムである。これから述べ る「死生学」の実践においては EBM はなく, まさに NBM の領域であり，その概念の理解は必須である。わ が国における NBM に関する活動は,「健康と病いの語 り,ディペックス・ジャパン」(DIPEx-Japan)によって リードされ, web site にその「語り」が揭載されてい る2)。また, 同サイトからイギリスでの一般向け, 若者 向けのサイトに入ることができる. Healthtalkonline の 中には「先天性心疾患の览をもった親」の項目もみら れる。

本稿において, 従来通りの量的分析の文献の引用も あるが, 質的研究や個別の記述の引用が多いのは, 死 生学の分野が正にNBM の分野にほかならないからで あることを理解していただきたい。

\section{死生学とは}

英語の Thanatology は文字通り「死学」であるが, 上 智大学で教鞭をとったデーケン氏は「死について学ぶ ことであるが, 同時に生き方を考えることなので死生 学とする」と言い, また, 同様の意味から 1904 年加藤 咄堂が『死生観』と題する書物を著している3). した がってわが国では「死生学」と訳すのが一般的であり， 本稿でもそれを踏襲する。

では実地臨床で死生学の位置はいかなるものか？ あるいは死生学の知識をどう現場で活用するか? そ れは, 人の死に関する社会心理などの諸事を理解し， 死にゆく人たちと取り巻く人たちが死を受け入れ，新 たな人生を歩み始めるための支援をすることといえよ う. シュナイドマンは「Thanatologist (死生学臨床の専 門家)の主な目標は, 死にゆく人に対してはよりよい死 (望ましい死)の達成のために, 残される人びとに対し ては身近な人の死をより良く受け止めるように助力す ることである」と述べている ${ }^{1 \sim 4)}$ ，そして，この実践に は，死にゆく人と死について話し合うためのさまざま な機会を捉えることが最も重要であり ${ }^{4)}$, そのことに よって, 死にゆく人は孤独の恐怖が和らげられるばか りでなく, 成長の最後のチャンスを生かすことになる, とされる5. CHD 览の死にこの考え方を適応すれば, 親の成長のチャンス, それは最後ではなく成長によっ て，亡くなった子の死の意味を親の残りの人生に活か せるのではないか, ともいえよう.

\section{日本人の死生観}

私自身の以前の経験であるが，あるアメリカ人の子 どもが亡くなった時, 家族は遺体を病院に置いたまま 帰宅し，翌日引き取りに来たことがあった，日本人は 遺体(故人：人格のある呼び方でもある)を一人にしな いため家族が病院の斎室に留まるのが普通だったの で，そのアメリカ人の行動は当時の私には理解できな かった，児の死後，十字を切って祈りをささげ帰宅し ていった彼らの死生観の根本は, 生死は神との契りの 中にあると思われ，これは日本人とは大きく違うと感 じている。では日本人の死生観とはいかなるものか?

広井によれば(6), 現代日本人の死生観の根底には三つ の層があるという，最も基底にある層は，すべてのも のに「八百万の神様」を感じる「汎神論的感覚」ないし は自然のスピリチュアリティがあるとしている，次い で仏教的な層で, 死は「永遠 (の生命)」「涅槃」といった 
抽象化・理念化されたイメージ, そして, 第 3 の層は, 高度成長期以降の個人の意義や存在を物理化学的な事 象と捉える「死は無である」とする考えである.

「死は無である」は唯物的であり，その他の層は日本 人の宗教観(汎神論)あるいは精神性ないし人間性とも いえよう，立川は7「生命」と「いのち」のニュアンスの 違いについて, 前者は生物学的医学的, 後者は人間的 文化的な意味合いがあると述べている，その「命」(両 方の意味で)が終わるときに死生観が問題になるが, 佐々木は人の死について ${ }^{8}$, 「ポイントとしての死 $=$ 死 亡時刻など」と「プロセスの死 $=$ 死の予感から, 肉体の 死を経過して, 心の受容へ至る時間経過」の両面があ るとして抢り, 前者が「生命の死」後者が「いのちの死」 と解釈できょう。プロセスの死は, 遺された者にとっ ては, まず「肉体の死＝ポイントの死」を認め, 次いで 生前の故人との関係が途絶したことを受け入れ，次に 故人との新しい関倸を再構築していく一連の流れを指 す. 後の二つの心理による死の受諾を佐々木は「関倸 性の死」と呼んでいる.

一方, 死にゆく人自身には関係性の死はあるのか? シュナイドマンは224), 死と取り組むことによって人は 二重の重荷を負うとし, 一つは魂の内面に打ける重荷, それは死に対する自分自身の心の準備であり, もう一 つは他人とのかかわりから生ずる重荷, すなわち愛す る人々に心の準備をさせ, 自分亡き後生き抜いてくれ るように心を砕くことである, と述べ, 死にゆく人も 関係性の死を意識していることを述べている. 鈴木は, 人は死の間際に, し残したこと, 言い残したことを成 し遂げようとする時間を持つと言い, 死にゆく人が周 囲の人たちに思いを語る, その貴重な時間を「仲良し 時間」と呼んでいる9,10).それは死にゆく人たちが周囲 との「関係性」を整理する一瞬であると理解される。こ れに関して今思い出す経験がある, 研修医時代, 受け 持ちの急性白血病の 8 歳の女児に, 毎日毎日嘔吐や疼 痛, 発熱など副作用の強い薬剤の静脈注射を続けた。 とても可哀そうで励ましになればと思い，時に小さな ベッドで一緒に捜昼寝をしたりした。しかし薬石効な く, 両親とベッドサイドで死にゆく姿を見守っていた 時, 彼女がパッと目を開き私のほうを見て, はっきり した口調で「先生，ありがとう!」とその言葉の直後息 を引き取った。彼女が私にくれた「仲良し時間」だった と思う. 8 歳の彼女が私との関係性を完結させたので あろう。

関係性を自己観からみれば,「自己を他者から切り離 すことができない『つながりの自己』」が日本人の特徵 で,この自己観ゆえに死においても関倸性が重視され
ていると考えられている. 対して, 欧米ないしキリス 卜教〜唯一神社会では, 個人は神との関係の中に生き ていて, 自己を他人から全く独立した主体とみなす「ア トム的自己」との考えが強く, 大井によれば11)キュー ブラー・ロスもこのアトム的自己の視点で死の瞬間 (後 述)を論じていると指摘している，それ故か, 彼女の見 方は，立川氏が書きとめている日本人の死にゆく人た ちの心理や行動12) と, かなり違っているように思う. 死に際しても周囲の人々との関係性を重んずる死生観 は, 日本人の文化思想と指摘されている「恥の文化」13) の表れともいえるのではないだろうか. ちなみに西欧 は「罪の文化」といわれていて, 先のアトム的自己観と も一致するものであろう。

死の現場においてはどうか.われわれは「今できる 最高の医療を行いました」と客観的な事実で説明する しかないが, これは身体機能の死ないし「生命の死」を 宣告しているのみで, 関係性を考慮に入れた死「いの ちの死」の宣告でない. 先にも述べたとおり，身体的な 死の宣告から「関係性の死」の納得への作業が始まり, その作業が一応の収束に達した段階で, 死が納得でき るものとなる。立川は12)自宅で家族に看取られて亡く なった寺田寅彦の死の様子を書いた付き添い看護婦の 日誌から「このような死に方は, たとえ最高の医療で なくても最善の医療ではなかったか」と,いわば「いの ちの死」の視点で述べており, 生命の死と同時に関係 性の死へ「自然に」移行していったことを示唆してい る。近い家族を亡くした遺族にとって最善と思っても らえる医療は,「いのちの死」を「納得」するスタート ではなからうか. 家族・遺族にとっての, この「2人称 の死」(死の「人称」は次項) は「生命の死」のような「3 人称の視点」での科学的アプローチだけでは解決が難 しい. 私たち医療者はこのことを自覚する必要があり, それ故に「 2 人称の死」にはグリーフケアが必要となる。 グリーフケアは極めて大きなテーマであり, ここでは 詳細に語ることができないので興味のある方は文献と してあげてある書物などを読んでいただきたい(文献 9, 19, 27 など).

\section{死の人称と CHD 診療}

すべての人は死を知っている. 芹沢の論文 ${ }^{14)} に$, あ る 58 歳の神父の「死そのものは怖くありませんが, 死 ぬのは怖いですね，いろんな人の死を見てきて思うの

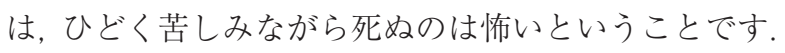
そういうとき, 人はとても孤独ですから。すなわち自 


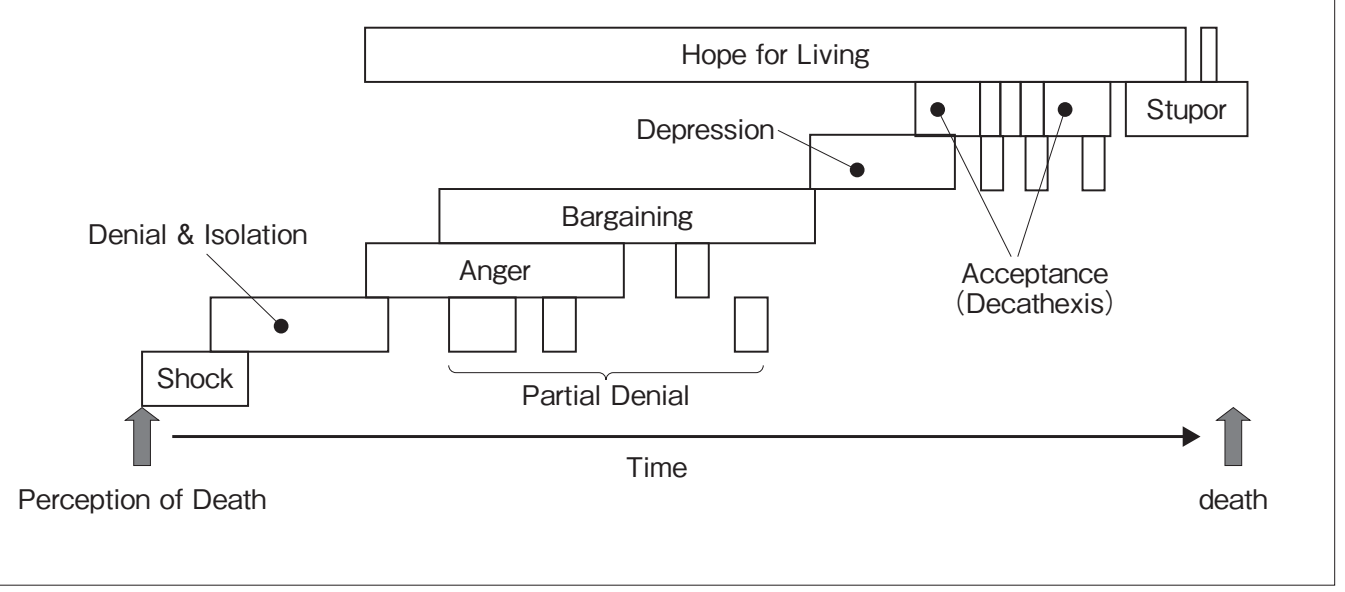

Fig. 1 Sequence of psychological reaction of dying.

(Arranged from reference 16)

分の死と他人の死は違うものです」との言葉が引用さ れて抢り, 自分の死と自分以外の死の違いを表してい る.ジャンケレヴィッチは死を「人称」で表し, 死者と の関係の違いによる死の見方を整理した ${ }^{15)}$. 自分の死, すなわち 1 人称の死は, 自己の死であり経験不可能ゆ えに不安, 恐怖, 嫌悪をもたらす。親子, 兄弟などの死 は 2 人称の死で, 他人事でなく客観視することが難し く苦痛が強い. 他人の死は, 3 人称の死であって客観化 対象化される，というものである。災害や事故などに よる見ず知らずの人たちの死はこの 3 人称の死である.

われわれが診る患者をこの「人称」からみると, 1 人 称の死は患者本人の死で, 今後, 死生学の観点から重 要になるのはACHD 患者本人の死であり, これに関し ては後に少し触れたい. 2 人称の死は無論家族である が, 特に母親にとって自分が産んだ CHD 児の死亡は 1.5 人称の死ともいえるのではないか. 3 人称の死は, たと えば学会などで出てくる死亡例や死亡にかかわる統計 などであろう。しかし，人間関係がある程度密になっ た患者の死は主治医にとっては 2.5 人称の死といえる かもしれない.

\section{死にゆく人の心理}

死は誰にとっても恐いものである，それは，苦痛へ の恐怖, 孤独への恐怖, 家族や社会の負担になる恐怖, 未知なる経験できない死への不安, 人生が不完全に終 わることへの不安や後悔, 自己消滅への不安, などで あるとされる5)。これらを知って生前から準備し取り組 むことは死の恐怖や不安を和らげるのに役立つ。 そこ
にこそ死生学を学ぶ意義がある。

キューブラー・ロスは16,17)，人は自らの死を認識する と, まずショック, 否認と孤独, 怒り, 取引(bargaining), 抑うつ, 受容 (acceptanceまたは decathexis)の段階・局 面を経るが，その間，一貫して生への希望を持ち続け る, ことを観察した(Fig. 1). その後の多くの研究者も, 表現こそ違え同様の情動の変化を示しているが, 同時 に, これらは順序立てて現れるのではなく, シュナイ ドマンの言葉を借りれば,「蜂が巣箱の周りを飛び回 り, 自由に巣箱に出入りするように, 種々の心理状態 が自由に飛びかいつつ，あるいは出現しあるいは消失 する状況」で「受容と否認を行き来する心理的動摇」と 表現している3-4)。ここで留意すべきは, ショック, 否認, 怒りなどの情動は, 死に直面するという不快で強い苦 痛に対する自己防衛であって, 健康的で自然な心の対 処法であるとされている，医療者を含む周囲の人々は そのことを理解して, 反発心や不快感を露わにしない で優しく見守ることが当人への大きな支援になる.

最終到達点とされる受容に関して, キューブラー・ ロスは「受容を幸福な段階と誤認してはならない。受 容とは感情がほとんど久落した状態で, 痛みが消え苦 闘が終わり，長い旅路の前の最後の休息の時である」 と述べている16,17). Fig. 1 の中の「虚脱」(stupor)の状態 である。しかし, キューブラー・ロスは同時に, 受容は 諦めとは違い, 勝利の感情であり平和な静䍀の感情で あるとしている。この視点は佐々木が述べる日本人の 死の受容に近い，すなわち，日本人は死と対決し無理 矢理死を飲み込むように受け入れるのではなく, 岩に 水がしみいるように「死」そのものが人に働きかける プロセス，それを自然に心で感じる営みとされる ${ }^{8)}$.人 
間が主体との思想ではなく，死が人に働きかけるとい う死を中心に考える日本独特の思想が心の深層にあっ て「死を納得」するのではないか，と述べている8)。 た「諦め」は仏教的には「諦観(たいかん)」でもあり， これは因と縁との関係を「アキラカニミル」意味で, 死 に向かって今できることは何か, 冷静に判断して前向 きに対処する態度である ${ }^{18)}$. 先に述べた，死にゆく人 が持つ「仲良し時間」はその一例ではなかろうか.

これらの情動や反応の軽重は患者によって異なる が, それぞれの患者のその時点での精神心理的状況を 汲夕取って, 臨機応変に, 医学的, 社会的, 精神心理学 的, 宗教的に対応することによって, 死への恐怖をい くらかでも軽くさせる可能性があろう．

\section{2 人称(家族)の死における遺族の死別の心理}

サンダースは19), 死別の悲しみには, (1)ショック, (2) 喪失の認識, (3)引きこもり, (4)癒し, (5)再生, の 5 段階 のプロセスがあり, このプロセスには個人差はあるが, 大きな苦痛は共通すると述べている，そして苦痛から 逃れる方法はなく, 経験して乗り越えなくてはいけな いと強調している。このプロセスに関してはほかに, (1)ショックと信じるのを拒む; 激しい悲嘆 ; 決意 (リ ンデマン), (2)喪失を取り戻したい欲求; 無秩序と絶 望; 再構成(ボウルビー), (3)ショックと否認; 意識の 発展 ; 回復 ; 喪失の解決 ; 理念化(エンゲル)などが提 唱されている20)。いずれも初期の段階には「怒り」があ り，いらだちに伴う怒り，八つ当たり的怒り，罪悪感か らの怒り, 内に向かう怒り(身体症状となって現れる), 無力感からの怒りなどで, それは周囲にいる人へ向け られることがある。ここで知っておくべきこととして, この現実否定は悲しむ人の心の破壊を防ぐ緩衝として 働くことが広く認められている。

死別の時に「人間は強くあるべき」との思いが強い と悲しみを十分消化できないままとなってしまう危険 がある ${ }^{19)}$ ．アティッグは20)，死別の苦痛に向き合う大 前提として, 強くあるべきではなく「人は脆弱である」 を認めることから始まるとしている，自分一人で解決 するのではなく, 悲しみを共有してくれる人の存在, 特に友人, 家族, 時に隣人, そのほか話を聞いてくれる 人，との交わりが大いに助けになったと述べる遺族が 多い19)，援助者は，そばに座り，ともに涙を流し，怒り に耳を傾ければ, 特段のアドバイスは不要あるいは無 用であろう，子どもを亡くしたある母親が「みんな私 を避けています，まるで私が伝染病か何かに罹ってで
もいるように‥と語っていて，このような孤独のな かでは癒しや再生は遠い.

悲嘆のプロセスは, 悲しみから逃げずしっかりと受 け止める「能動的な営み」であり，怒りを含めた種々の 感情を抑え込まないで, 自らの人生を故人のいない環 境で生きることを「学びな招す」作業であるといわれ $3^{19,20)}$ 。この作業を通して, 遺族は現実に戻っていく が, 故人との新たな関係(思い出のなかに生き続けるな ど）保ちつつも, 以前とは違い, 愛する者が目の前に は居ない世界であることも，また，納得する必要が ある。

患者が死ぬ時の医療が遺族のその後の心理プロセス に影響するか？について, サンダースは次のように 述べている ${ }^{19)}$. 死別の瞬間が遺族のショックからの回 復〜再構成への出発点であり, 死者へはっきりと別れ を告げることが大切である，そのため医療者は遺族が 患者の死の場に立ち会えるように配慮するべきで，し ばしば行われているように，まず死を告げ, line 類を整 え, 清拭, 化粧の後に, 死後の最初の面会とすることが 正しいか？との疑問を呈している，死にゆく時間を 死者とともに過ごせず，死者を孤独のまま一人で逝か せた，という遺族を数多く経験しているが，その思い は，その後一生後悔を残し衰失の傷を引きずる結果と なる。

\section{子どもの死における親の心理}

親にとって子どもは定義上 2 人称ではあるが, 子ど もからみた親や兄弟間よりは距離が近いように感じら れる。死の場面では特にそうで, CHD 览の死の場合, 母親が自責の念を強く抱いており，1.5 人称の死とも呼 べよう.この章では, 前章に述べた一般的な 2 人称の 死の場合を踏まえ, 子どもの死における親の心理・情 動を自らの経験を交え文献や関連の書物から紹介して みたい.

1. 児の致死的ないし重症疾患の診断と親の心理

Drotar らの研究が知られている21). 致死的ないし重 症疾患の児の出生は親にとって「期待された正常児の 衰失」あるいは「かわいい子どもが死のスポットライト に照らされること」であり，その後の心理反応を Fig. 2 のように示した。 これは, 本人の死の認識による心理変 化 (Fig. 1)，家族の死に対する遺族の心理(前述)とほぼ 同様である. 初期の段階のドクターショッピングと呼 


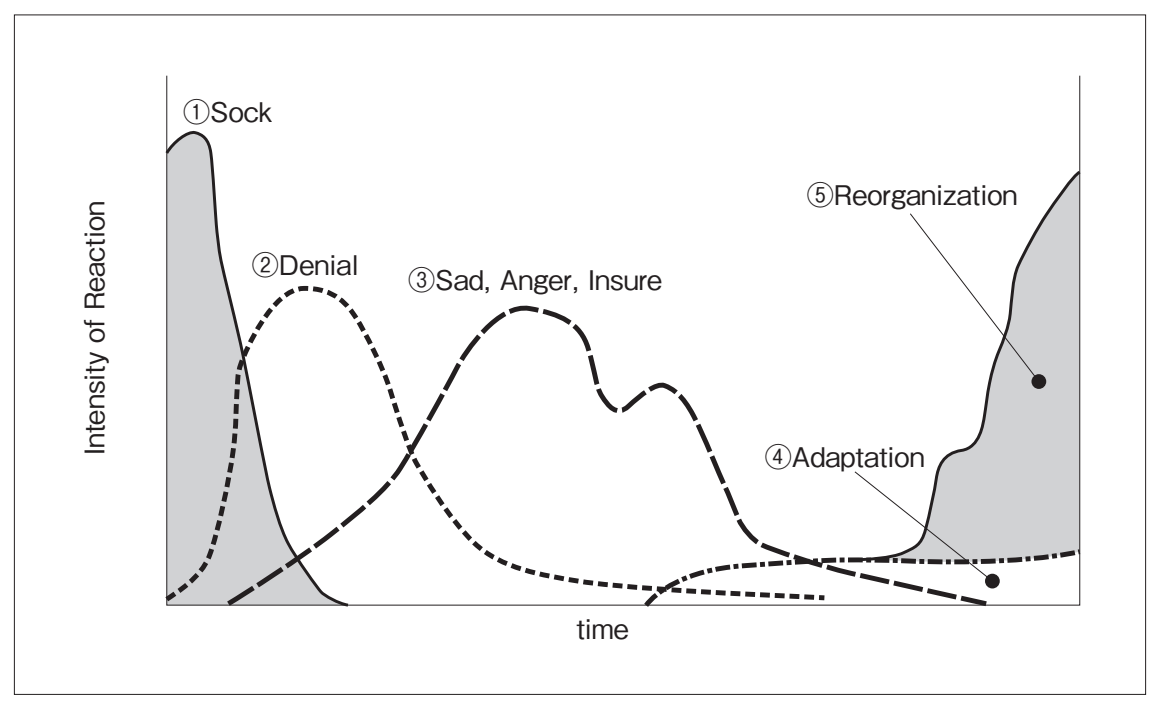

Fig. 2 Hypothetical sequence of parental reaction to the birth of a malformed infant.

(Arranged from reference 21)

ばれる他医への受診は, 従来, 否定的行為とみなされて きたが, 現実を確認する行為でもあり，現実を認めざる を得ないとする親の葛藤の表われでもあると指摘され ている22).

親の一連の反応への医療者側の対応として, 早期か らの支援は効果的で，母児同室の促進なども効果をも たらす場合が多いと述べられている，特に小児科医の 役割は大きく, 最善の医療の提供は当然, 医師の availability（いつもいる，いつも心を寄せている)が重要 である。この際，医師ないし医療者が親の一連の心理 変化を「正常の反応」と理解することが前提となる. 親 に児の状況の説明をする時に, 全く伝わらない, やた らと突っかかってくる, などはわれわれが日常しばし ば経験することである。しかし，それぞれを「ショック あるいは否認の心理状態」怒りの状態」と知って対応 し, 主治医として親の心理的苦痛を共有し理解してい ることを言葉や態度で示すことによって, 親の苦痛を 和らげるだけでなく，主治医への信頼は増す．ACHD 患者が幼少期から診てくれている医師に全幅の信頼を 寄せているように感じるのは, 初期対応の仕方による 可能性も考えられる。この点は ACHD 患者を内科医療 へスムーズに移行させる一つのヒントではなかろ うか.

個々の患者への対応に際して留意すべきことは，医 療者からみれば疾患自体の軽重はあるが, 疾患を抱え ている本人や家族にすれば, 誰かと比較する余裕もな く，それぞれの立場で深刻な痛みを感じている23)。こ のことは私も経験した. 4 人部屋で 3 人の完全大血管 転位症 $(\mathrm{TGA})$ の乳児のなかに入院していた動脈管開存
症の子の母親が私に「TGA の子の親に，あなたの子は 軽くていいね，といわれた。でも，うちの子は軽いかも しれないが，つらい気持ちは同じです」と語ったのを よく覚えている。ついつい「軽い」疾患だと「軽い」対 応になっていないか, を反省した。

親は抑うつ的感情から気を取り直して明日へ向う 「再構築」の作業を行うが, これには夫婦間の支え合い が極めて重要であることが示されている211。この際, 父親と母親の反応・適応が違うことが, Down 症候群 児の両親を対象とした研究で示されている24). ショッ クからの心の回復には二つのパターンがあり (Fig. 3), 着実に回復していく group 1 は父親に多いが, 母親は周 期的変動を繰り返してなかなか回復に至らない「慢性 的悲哀 (sorrow)」の group 2 の反応が多い. また, 両親 の気持ちの比較では, 母親が罪責感, 否定的感情, 気持 ちの交流希望, 当惑感, を強く感じているのに対して, 父親にはそれらの強い感情はなく, 両親, 夫婦間で心 の動きにギャップがあることを示している。このこと は，児の死の際しても同様と思われるので，上く理解 して対応する必要がある。

\section{2. 胎児診断}

母親は胎児の成長を直に感じる, それ故, 未熟児や 病児の出産は母親に特異な反応を惹起する. クラウス らは母子関係の 4 つの心理学的課題を示している25). それは, (1)死への心の準備 (予期的悲嘆)で, 胎内での 児と築いた関係を取り消す悲しい作業, (2)病児の出産 (「失敗」)を認めざるを得ないこと, (3)出生後, 中断し 


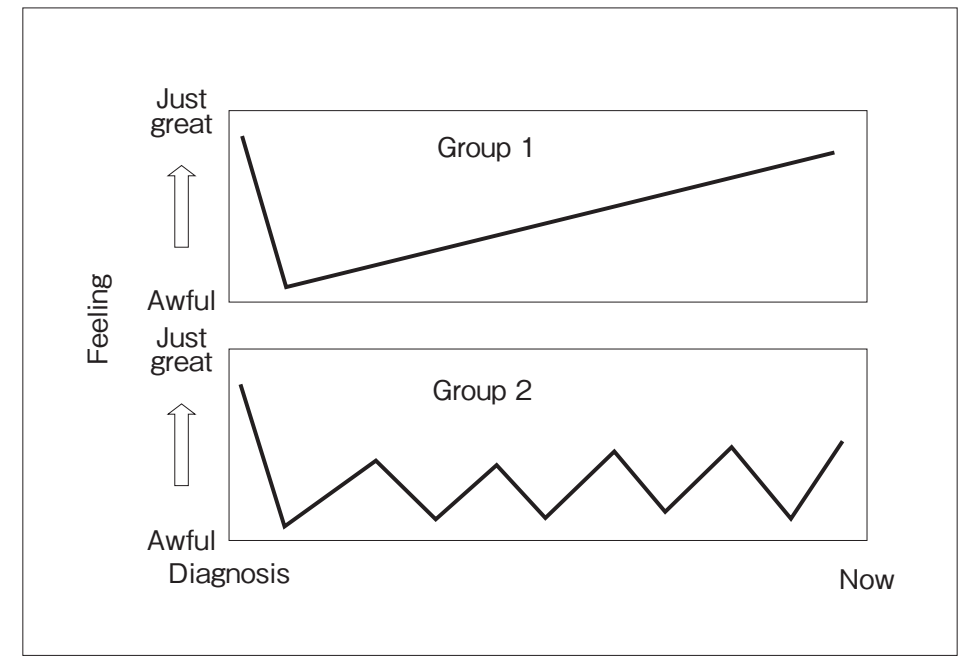

Fig. 3 Time-bound (Group 1) and Peaks-Valleys (Group 2) patterns of adjustment.

(Arranged from reference 24)

ていた児との関係の過程を再開し, 児の生存への希望 への切り替え, (4)览のニーズや成長の理解, とされる. これらは胎児診断にも当てはまると思われ，親，特に 母親への対応の際に心に留めておくべきである.

Breeze らは胎児の致死的疾患診断例での緩和ケアの 意義を報告している26). 緩和ケアの詳細は別に譲るが, それは，蘇生や延命を行わず，宗教的あるいは精神的 支援者とのリエゾン, 多職種間での児や家族の情報の 共有による terminal eventsへの心構えの構築，患者会な どの紹介，上級新生児科医の出産への立会い，産後の 定期的なフォローによるグリーフケア，死後の（剖検結 果などの) 情報の伝達, などからなる，胎児診断後にこ の方針を受け入れた 20 例中 8 例では, 緩和ケアが, 胎 児を慈しめる時間, 胎児と残された大切な時間を作っ た可能性がある,としている。

\section{3. 親にとっての子どもの死 $8,19,20,23,27)$}

子どもを亡くした母親の心理には, 非連続性(子ども の存在の消失による時間の停止), 混乱, 適応の局面が あり 27), この局面あるいは反応はすでに示した「死に ゆく人」(Fig. 1)，「児の致死宣告に対する親」(Fig. 2)の 心理反応とほぼ同様と思われる。ただ，親兄弟などと の死別と違い, 子どもを失った親，特に母親は身体の 一部を切り取られたような気持ちになるといい，また， 子どもを自分と同一視する傾向にあるため, その悲し みはより強く, 罪悪感・自責感, 無力感など抑うつ的 な感情が強調される。サンダースによれば19)，その悲 しみは子どもの死後次第に強まり 3 年目にピークを迎
え，しばしば $10 〜 20$ 年，時に一生続くともいわれる. また，親たちは，子どもの肉体的な死は理解できるが, 存在が消滅したとは思えず8)，あの子が無になったなん てとても受け入れられない, などと苦しみが強い23).

それでも，親たちはこの衰失感を抱えて生きていく ため, 死別経験に何らかの意味付けを試みる19,27). たと えば，自分を必要とする人に何かをしてあげることが， 自分と死んだ子どもの人生に意味を与える。私の経験 であるが, 強い心不全のため入院中の幼児を両親の希 望でディズニーランドに行かせた，児は 1 週間後に亡 くなったが, その半年後から，母親は「私の経験を分か ち合いたい」と定期的に来院し入院中の重症児の母親 と対話を繰り返していた。 まさに子どもの死による人 生の新しい意味付けであった. 子どもの死を他の人と 共有することは, 自分たちの物語を発展させ, 親子関 係に新たな意味を与える重要なもので, 遺された親た ちの人生の再構築に寄与する ${ }^{19,27)}$. 死産児, 流産児にお いても同様で, それらの児には望みを託した人生があ り，語るべき，聞くべき，記憶すべき物語があり，この 物語を通して亡くなった者を愛し続けることができ20), 単なる岥失には終わらせない.

では死別の苦痛の緩和は可能か？ 発達障害の子ど もを慢性疾患で亡くした母親が, 亡くなった子どもの 生涯や苦しみ, そして死に何らかの個人的な意味を見 出せた場合には, 丧失の苦痛が軽いことが示されて いる27)。これは死を事前に覚悟し，ある程度まで準備 ができていたことによると思われ, 重症 CHD の場合に も重要なポイントではないだろうか.この「準備」につ いては後でも述べる。 
子どもの死後の人生の再構築には夫婦二人の協力が 必要なことは, 览の致死疾患の告知からの再構築の場 合(前述) と同様と考えられる.しかし, 子どもの死後の 親の悲しみのプロセスは母親と父親では違い(Fig. 3)， 母親は慢性的悲哀を感じ, 父親の悲しみは次第に軽減 する場合が多い19,24)。しかも, 普通, 父親は「強いこと が男らしい, 家族を守る, 問題を率先して解決する」な どの態度を取ろうとして悲しみを押し殺すので, 悲し みや大きな丧失を感じていないかのような誤解を与え ることが多いといわれる19)。この点も夫婦間にギャッ プを生じて互いの「再構成」を妨げるばかりでなく, 遺 された同胞がいる場合には，これが両親の不仲とも受 け取られ，同胞のグリーフワークに支障を来すことも 危惧される。

\section{4. 子どもが死にゆく時の医療側の対応について}

われわれは時として子どもの余命を告知せざるを得 ない場面に遭遇する。しかし, この際, 実際の数字(あ と何年など）を出すことはよいことではなく，むしろ有 害なことが多いと，キューブラー・ロスは述べてい る ${ }^{17)}$. 事実, 私も, 無脾症児の親に新生児期に「20歳ま ででしょう」と告げたことがあったが, 児が 20 歳になっ た途端，母親が極度の神経症となってしまった経験が あった. しかし，死の予感や予断を持ってもらうこと は大切であり，先にも述べたように，それによって死 の衝撃を和らげる可能性がある。この点について キューブラー・ロスは, ペアレントケア (親子同室の入 院）は，家族全体に子どもの病気の実態や医療内容を理 解させることに役立ったうえ, 親に子どもの死の可能 性への心の準備をさせたと, その有用性を述べてい る ${ }^{17)}$.わが国では入院中の子どもへの親の付き添いは 原則的に認められていないが, 重症疾患の場合はいう までもなく, 親子の attachment の意味からも，再考すべ き事項かと思う.

実際の死の場面について, 佐々木はインフルエンザ 脳症で子どもを亡くした親たちの話を紹介している ${ }^{8)}$. 子どもの死期が近い時, ただ延命ではなく, 親は子を 抱きたいと望むことが多く, ある母親は「最後の肌の 温もりを感じたことが，どれだけその後の生きる支え になったことか」と語った。これは，私たちがしばしば 経験する「子どもを一人で逝かせてしまった」と悲し む親の心情への大切な配慮であろう。これも自らの経 験であるが，単心室で手術不能の乳児の家族が，思い 出作りのために両親・兄・祖父母全員でその子を連れ てディズニーランドに行きたいといってきた。リスク
のことを話し了解のうえで行ってもらったが，その子 はそこで祖父の腕に抱かれたまま亡くなった，後日， 全員で来られて「楽しい時間でした。一人で逝かせる のではなく，皆が見守る中であの子もきっと幸せだっ たと思います。ありがとうございました」といわれた。

親の多くは子どもの死に際して怒りを表すが,この 怒りが, 目の前にいる医師, 看護師, 救急隊員ほか, 子 どもの死にかかわった誰に対しても向けられることが ある. CHD 児の死に直面する両親, 特に母親の怒りは 強いように感じるが, これは自責の念, 医療選択への 後悔, 非 CHD の子を持つ親への妬み，などが重層的に 蓄積して死の瞬間に噴出すると思われる，その激しい 怒りは時には祖父母や親切にしてくれた友人にさえ向 けられる。この情動は先にも述べたように「正常の心 理」の一つであるが, 怒りの元となるのは「子どもを救 うためもっと何かできたはず」「それをやらなかった， あるいはミスした」との思いもある。さらに，われわれ が銘記しておくべきは, 親が死に立ち会えなかった, 主治医以外(たとえば研修医など)に死を最初に告げら れた，なども，死を受け入れ難くしている要因であ る ${ }^{19)}$. 心や情が尊重されて初めて人は救われるし, 死 を認めることができる。これこそがまさにわれわれに 求められることであろう。理セラピストが普及して いないわが国では, 患者は, ある意味, 医師にセラピス トとしての役割を求めているように思える。そのセラ ピストとしての医師は洞察力を持って患者家族の気持 ちを汲み取って対応すれば，それは大きな支援となり 得る16)。この医師の支援は, 昔から使われてきた「ムン テラ」にほかならない. 今, 患者医師間の対話をすべて Informed Consent(IC) という風潮にあるが, IC とムンテ ラは全く違うものであると筆者は考えている。

\section{子どもの死の理解}

\section{1. 子どもの自分自身の死についての理解}

キューブラー・ロスによれば, 3,4 歳の子は, 自分 の死を口に出すことがあるし，死が迫っていることに 気付いている，そして，8，9歳以後になると死を永久 的な出来事とみるようになる17). サンダース, ベッカー も同様の考えを示している19,28).ささらに, シュナイドマ ンは「あなたが最初に死を意識したのは何歳ですか？」 という問いの調査の結果を示しているが4)，それによれ ば, $3 \%$ の人が 3 歳未満, $33 \%$ の人が $3 \sim 5$ 歳, $52 \%$ の 人が 5 〜 10 歳と答え, ほとんどの人は 10 歳までに死 
を意識することを示している，私のかかわったある成 人患者が, 3 歳の時に同室の子が白いシーツを被せら れてストレッチャーで運び出されるのをみて「あの子, 死んだのだ」と同時に「私は死にたくない」と思ったこ とを覚えている，と語り，その年齢で死を認知するこ とを教えてくれた、たた，これらは観察者の印象的な 記述であって, 子どもの死の理解の深さはわからない. 死の特性は, 普遍性㧍よび不可避性, 身体の機能停止, 非可逆性および最終性であり，「子どもは死を理解でき るか? 」を論ずる場合, それぞれの特性の理解で死の 理解の程度が評価される。

志田らは, 日本の文献をレビューし小児の死生観を 考察した ${ }^{29)}$. それによれば, (1) 3〜 5 歳では, 概念の理 解は不十分であるが, 自分の死の予感や不安を感じて いる, (2) 6〜9歳で死の概念をほぼ理解できている, (3)高年齢ほど生まれ変わりの思想をもち, 死の恐怖を 持っている, 子どもの死生観に影響を及ぼす要因とし て, 祖父母との同居, ペットの飼育経験, 同病者と共有 する時間, 宗教, コミュニケーション, 祖父母との死別 体験, 同病者との死別体験, 自分自身の病気体験や入 院体験がある, としている。

仲村は 3 13 歳までの 205 名の子どもへの個別面 接の研究を報告している30). その結果, (1) 3 ～ 5 歳で は死と生が未分化で, 死の意味がわかっていない, (2) 6 〜8 歳で死の現実性をほぼ理解している, (3) 9 11 歳 で普遍性の理解が進み,「生まれ変わり思想」が増えて くる, (4) 12,13歳では, さらに扮盆の習慣など霊的精 神的な回答が増えた。死の特性と年齢層の関係では (Fig. 4), 若年では「普遍性」の理解が特にそしいこと がわかる. 仏教を基盤とする「生まれかわり思想」につ いて「ある」との回答は, それぞれの年齢層で, $0 \%$, $10 \%, 18 \%, 35 \%$ 年長児で増え, この思想は諸外国の 研究とは違っており, 日本の文化的影響と思われる, と述べている，その仲村は考察として，死別体験の影 響について「死の概念発達を促す」「影響しない」「概念 を歪める」の諸説がある, として, 一定の傾向を認めて いない.

以上を総合すると, 子どもたちは小学校低学年には 死を理解していると思われる31). ところが, 現代にお いては死の場面を子どもから遠ざけているのが現状で あろう。果たしてそれでよいのだろうか？ 志田は, 致死的疾患のある小児患児本人に対しても, 死を夕 ブー視せず，あらゆるきっかけを捉えて病気や治療の 情報を提供し, 共有する時間を設け, 適切なコミュニ ケーションをとることが, 死の恐怖や不安を軽減する ことに繋がるとしている29). 子どもを死から遠ざける
のはよくないことは, 次々項に述べるようにほかの研 究者たちも全く同じ考えを示している.

\section{2. 子どもの自分自身の死に対する恐怖とは}

子どもにとって自身の死に対する恐怖の主なものは 何であろうか？ キューブラー・ロスは, 小児の入院 では子どもにとって隔離〜分離への恐怖が大きく, 死 に直面した子どもたちは，実際の死のプロセスの恐怖 よりも，死による愛する人々との離別を恐れると指摘

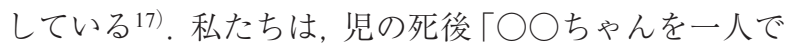
逝かせてしまった」と嘆き悲しむ親の姿をしばしば経 験するが, 親たちは, その子の死への自責の念とは別 に，児が死に際して孤独を恐れていることを本能的に 知っているのではないだろうか. キューブラー・ロス は, この恐怖心の軽減緩和にペアレントケア (親子同室 の入院)が有用であり, その安心のなか, 死にゆく子ど もたちが短かった生を完全に成就していけるよう助け るのが大人たちの義務であり, 子どもたちが受ける権 利である，としている17)。したがって，ペアレントケア は，児にとっても親にとっても死を受け入れることへ の大切な準備となるであろう。

\section{3. 死に遭遇する子ども}

現代社会では, 死は一般にタブー視され, ましてや, 「守るため」として子どもへは完全に遮蔽されている。 しかし, 子どもたちは日常的に 3 人称の死やバーチャ ルの死 $(4$ 人称の死? ) をみている. したがって, 本当に 守万うとするのであれば, 死を黙殺するのではなく現 実の死に伴う苦恼や悲嘆などを理解させることが, 子 どもを「死の実体験のよる衝撃」から守ることにな る28). サンダースや相良は, 死は生の一部であり, 死を 子どもの目から隠すことは子どもの目を人生そのもの からそらすことになる, また, 子どもから死を隠せば 子どもは一人ぼっちで死に向き合わなくてはいけなく なる, と警告している19,32,33).

一般に, 親せきの死などを経験した子どもは悲しみ を表情や言葉に出さない傾向にあるか28), あるいは2, 3 の質問をしただけで友達と遊び出したりすることが ある ${ }^{19)}$.これらの行動は子どもが死を理解していない と誤解させるが, 子どもも死について梁く考え, 悩み, 悲しむ感情は大人と違わず，その影響はむしろ大きい とされる. 子どもが死の事実を消化する方法が大人と は違うことを理解してあげなくてはいけない19). 特に 思春期には相談できず処理できないまま抱え込んでい 


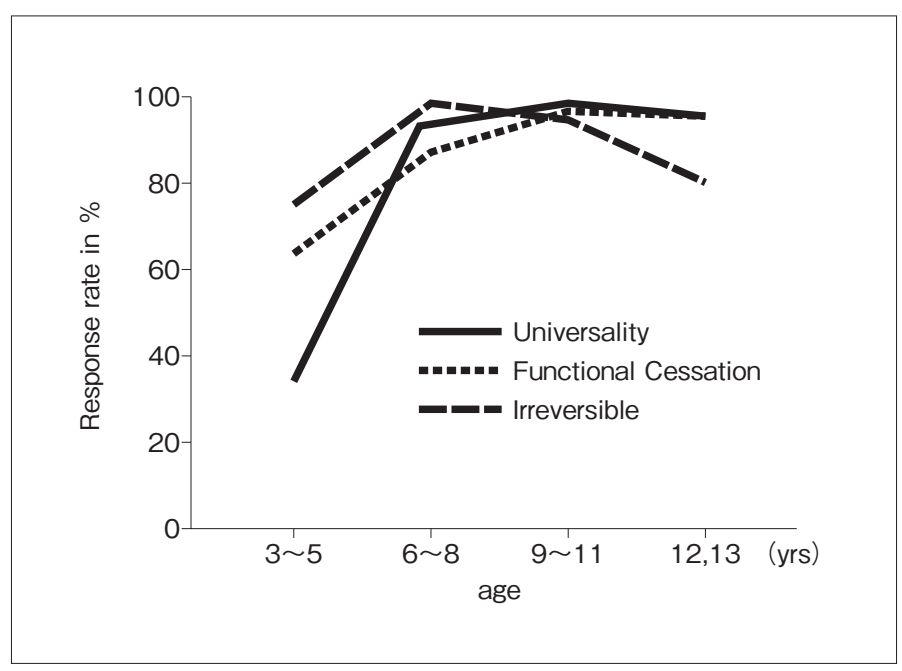

Fig. 4 Understanding the characteristics of death in the 4 age groups.

(Arranged from reference 30)

ることが多く、これを「未解決悲嘆」「困難で複雑な悲 嘆」といい, 後にADHD, 自殺や殺人につながる可能性 も指摘されている28).

一方で，あまりにも詳細な情報や説明は年齢によっ ては子どもを当惑させるので, 子ども自身から質問さ せるように仕向け，言葉に頼らず，遊ぶこと，絵を描く こと，泣くことなどを通して表現できるようにしてあ げる19). 大事なことは，子どもが一人ぼっちではなく， むしろ，家族の一員として悲しんでいることを実感さ せ, 安心させることである ${ }^{20)}$ 。この際, 大人のほうから 子どもに対して「㧍じいさんは遠い国に行った」「扔母 さんは春になったら帰ってくる」などという幻想を創 り出すような説明は, 子どもの死の理解を混乱される 恐れがあるので, 正直に現実を受け入れさせるように 辛抱強く対応することが必要である。

\section{(1) 同胞の死}

同胞を失うと，亡くなった兄弟に対して「愛増入り 混じった感情」「生き残ってしまったことに対する罪の 意識」が残ることが多いとされる。

小澤らは, 悪性腫瘍で死んだ 9 人の小児の同胞にイ ンタビューを行い, 彼らの心情についての質的研究を 発表している ${ }^{34)}$. CHD と共通する部分も多いと思われ るので紹介する，結論として(1)幼少時のほうが年長児 より死別を自然に受け入れている, (2)正しい情報を与 えられなかった同胞は死別の受容が困難である, とし ている，その解決法として，年齢・発達段階・理解能 力に応じて, 闘病中の同胞が死に至るとの説明を繰り 返すことが遺された同胞の受容に極めて重要で，また，
遺された時間を一緒に過ごすことや宗教は受容の助け になると述べている，そして「もっと知っていれば, $\cdots$ ができたのに」との同胞の言葉を紹介している。この 点はクラウスも指摘している ${ }^{25)}$ 。ただ, 詳細な説明が なくても，家族が患児を含め一緒に過ごす時間を持て た場合には，同胞の受容の助けになっていた，この意 味からも在宅医療や入院中の外泊の意味は大きいと思 える。

Hogan らの思春期を対象とした研究によれば35)，同 胞との死別の悲しみを受容する助けになったのは, 自 分自身，家族，社会，友人，時間であったが，注意す心゙ きは，自分，家族，社会はむしろ妨げになることもあっ た、「家族が妨げになる」とは意外であるが，両親の不 和(前出：グリーフの違いによる), 両親の落胆の継続 による同胞の「置き去り」, などが要因となる。この点 を留意し，生き残った同胞に愛情と思いやりをかける 必要がある。 サンダースはこれを, 子どもを守る「安全 ネット」と述べている19).

\section{(2) 親の死}

親の死後, 子どもたちは周囲の大人たちにしばしば 忘れられる，それは大人たちが全く気に留めないので はなく，とても重い現実をどう話せばよいかわからず に避けているのが現実であろう，先に述べたように， 子どもは死について大人と違った考え方や行動をと る。黙って引きこもって孤立する，大声で嘆き悲しん で大人の注意を引く, あるいは「お母さんは春休みに は帰ってくる」といい，その間の生活のことを考える， などである. 大人たちは，この反応を見守り，時間をか 
けて現実を語る必要がある。特に，思春期はそれ自体 難しい時期なので, 彼らの話に耳を傾け, 罪悪感であ れ, 怒りであれ, 悲しみであれ, それらの感情を表に出 させないと, 先に述べたように「未解決悲嘆」に落ち込 んでしまう危険がある16).

芳賀らは, 小学生を対象に親の死を仮定したアン ケート調査を実施している36)，それによれば，まず，死 なないでほしいとの願望が強い. 次いで, 高学年では 否認や逃避などの感情が強くなるが, これは死の認識 が年齢とともに深まることによると考えられる。また， 何も知らないで急にいなくなるのは困る, もうすぐ死 ぬとわかったら，そばにいてあげたい，そして何かし てあげたい，と答えている，仮定の設定なので現実の 場合と異なる可能性はあるが, 子ども達の心情がよく 汲取れる。

\section{成人 $\mathrm{CHD}(A C H D)$ 患者}

ACHD 患者の増加により, 本人の死はもとより家族 が残されることが問題となり, われわれはその対応に 心を配らなくてはいけなくなる. 普通, 癌など死を予 感させる疾患に罹ると,「死の人称」は 3 人称から突然 1 人称へと移動する ${ }^{14)}$. ACHD 患者は, 疾患自体が持つ 性質(「心臟病」は死を想起させる) 拈よび真の長期予後 がいまだ不確定なため, 本人は成長につれて死の認識 が深まるとともに自らの死，すなわち 1 人称の死を心 のどこかで感じながら生きている，現代では医療の進 歩がそれらの意識を表面上薄めているとはいえ, 親は ACHD のわが子の死 $(1.5$ 人称の死)を密かに危惧し, 何 歳になっても「あの子を看取るまで死ねない」と罪の 意識と償いの気持ちを持ち続けていることを日頃実感 する。ささらに $\mathrm{ACHD}$ 本人が結婚すれば配偶者は 2 人称 の死が頭をよぎるであろうし, さらには子どもが生ま れればその子どもも成長につれて 2 人称としての ACHD を持った親の死を仮想のものではないこととし て意識せざるを得ない。これらの不安は, ACHD 患者 が具合悪くなったり入院したりした場合に現実性を帯 びてくる、また，しばしば経験することであるが，ほか の $\mathrm{ACHD}$ 患者の死の報に接した場合, ACHD 本人は否 が応でも自分 (1 人称) の死を意識するし, ましてやそ の死が同年代であればその不安や恐怖は強い。すなわ ち, ACHD 患者の診療にあたっては, 年老いた親にとっ ての子ども (ACHD 患者)の死, 同胞がいれば成人後の 兄弟の死, 結婚した場合には配偶の死, ACHDを親に もつ子どもにとっては親の死, そして本人の死という,
極めて重い多面的な課題を思わざるを得ない。この課 題に立ち向かう人たちを日頃からどのように支援する かは, 先に述べた諸事項を参考にできることもあれば, $\mathrm{ACHD}$ 特有の問題もあろう. 今後の大きな課題である.

私の患者のなかで, 本人が何か身体に不具合を感じ ると「先生, 私, いつまで生きられますか」と尋ねる人 がいる。これに答えるためには, 疾患の自然歴や術後 歴など平均的なデー夕はあるにしても，その人にあて はめられるだけの正確なデー夕はないし, 先にも述べ たように「あと何年」ということは，むしろ有害である と考えられる.この場合, 筆者は, 平均的デー夕ととも に類似の病態で長生きしている症例のことを話すよう にしている. 正否は別にしても, このことによって ACHD 患者は大きな不安のなかにでも希望の光をみ て, その後の人生を送る勇気を得ているものと期待し ている。この点から ACHD では長生き例の症例報告は 極めて重要であると考えている。

多くの何らかの医学的問題を抱えた ACHD 患者は, 健常者と同様の余命があるとは考えていないように思 う。事実,「生きている間」,「身体が動く間」にやりた いことがあるという患者が少なくない.内容はさまざ まであるが, 家族を残したい, 誰かの役に立ちたい, 生 きた証を作りたい，などである，故安藤正彦博士によ る「青年の生き方」調查では (Table 1), ACHD 青年は健 常者に比べて「のんき (easygoing)」が少なく「社会のた めに」との回答が多い37).このデー夕は，のんきにはし ていられないと感じる「ぼんやりした余命の予測」と, いま生きている, あるいは周囲や医療の浍で生かさ れている「いのち」の意義をしっかりと考えているこ との表れといえよう。これら前向きに生きる ACHD 患 者の積極的支援ないし応援は, それがたとえ医学的合 併症の出現を早めたり余命短縮のリスクを高めたりす ることがあるとしても, 彼らの人生にとって極めて重 い意味を持つのではなからうか. 立川は多くの著名人 や教養人の死を眺め「たとえ健康を失っても病気が治 らなくても, やりたいことを優先することもあれば, ゆずれない自分というものがある. 自分の運命は医者 に任せるのではなく, 最終的には自分で決めるもので ある」と書いて抢り, この点から QOL を「人生の質」

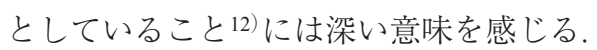

そのような生き方はなにも教養人に限らず一般にも ある。以下は 1994 年 6 月 19 日の朝日新聞に掲載され た記事の一部である。

30 歳代のご婦人の話：数回の手術にもかかわらず, 脳腫瘍が悪化・転移して, 歩けなくなり, 耳が聞こえ 
Table 1 Prospect of life style of young adults.

\begin{tabular}{lcc}
\hline & General population & Youth with CHD \\
\hline Be honest/noble & 9 & 14 \\
For the Society & 2 & 11 \\
Easygoing & 15 & 5 \\
On my own pace & 57 & 68 \\
Become wealthy & 12 & 2 \\
Winning fame & 4 & 0 \\
\hline
\end{tabular}

ず目が見えなくなった。もうこれ以上の手術は止めて, そのままでその後を生きよう, と決心した時の詩の一 節である。

「訴え」

私は, 最重症の障害者です。一人でできることはと ても少ないのです，他人の助けを借りなければ生き続 けることは, たぶん困難でしょう。でも・「禁治産者」 ではないぞ,「考える」能力はあるんだぞ, 物事を選択 する権利と，いかに行動するかを決める権利は，ある はずだ，自分の人生を，いかに生きるか，決めるのは私 です。

\section{「友人への手紙」}

私は歩ける足がないので, 広範囲の行動はとれませ ん、だから、どれだけ多くの人たちの心を動かしたか でなく，どれだけ梁く一人のヒトの心に沁みいったか で, ヘレンケラーと張り合っていきたい.

\section{結 び}

故高尾篤良博士は, 死期が予測され重症であればあ るほど，患者・家族の立場に立って，心からケアして いる態度, 感情を示すことが大切である, と述べてい る ${ }^{38)}$ ，穴のために医療者は，医療的にできることがな い場合にでも，患者・家族に見捨てられた気持ちを持 たせないように, 繰り返しベッドサイドを訪れること が大切である，患者・家族が述べているが，上級医師 （オーベン）が時々訪れるよりは，研修医であれ受け持 ち医の頻回の訪室が患者にとっては心強い支援にな り，とてもありがたい，という。患者・家族との実際の 対話にあたっては, メラビアンの法則が示すように, 意思や気持ちの伝達には表情 55\%, 口調 38\%, 言語 7\% で, 非言語のメッセージによる伝達が 9 割以上を占め ているとされるように ${ }^{39)}$, 相手の顔や目を見て直接話 しかけることが重要である。しかし注意すべきは，自
らの死生観を相手に押し付けることがあってはなら ず，それぞれの死生観を尊重することが基本である。 患者が最期に向うとき，傍にいて患者の気持ちを汲み 取り支援することによって死の受容の助けになるばか りでなく, 患者の死後も主治医への信頼が続き,さら には医療への信頼も維持されることを期待したい.

\section{【参考文献】}

1) Greenhalgh T, Hurwitz B: Narrative Based MedicineDialogue and discourse in clinical practice. Br Med J 1998

2) 健康と病いの語りデイペックス・ジヤパン: http://www.dipex-j. org/一般向け:

Healthtalkonline: http://www.dipex-j.org/outline/906.html 若者向け: Youthhealthtalk:

http://www.dipex-j.org/outline/1956.html

3) 島薗 進: 第 1 章. 死生学とは何か, 日本での形成過程 を顧みて. 島薗進, 竹内整一(編); 死生学 [1] 死生学と は何か. 東京大学出版会, 2008, pp9-30

4) シュナイドマン ES: 白井徳満, 白井幸子, 本間 修(訳): 死にゆく時一そして残されるもの. 誠信書房, 1980

5)井手敏郎：2時間目：ブッダの死生学講座. アスペクト 社, 2012

6) 広井良典: 第 6章 生と死の時間 - 深層の時間への旅. 島 哣 進, 竹内整一(編); 死生学 [1] 死生学とは何か. 東 京大学出版会, 2008, pp137-160

7)立川昭二：日本人の死生観. 筑摩書房, 1998

8) 佐々木恵雲: 臨床現場の死生学一関係性に見る生と死. 法藏館, 2012

9)鈴木秀子: 死にゆく者との対話. 文春文庫, 2013

10)鈴木秀子: 死にゆく者からの言葉. 文春文庫, 1996

11)大井玄：第 9章. 自分の死を死ぬとは. 島溒 進, 竹内 整一 (編); 死生学 [1] 死生学とは何か. 東京大学出版会, 2008, pp211-224

12)立川昭二：臨死のまなざし. 新潮文庫, 1996

13)ルース・ベネディクト著：長谷川松治(訳)：菊と刀. 社 会思想社, 1969

14) 芹沢俊介：第 7章. なぜ人は死に怯えるのだろうか. 島 薗 進, 竹内整一(編); 死生学 [1] 死生学とは何か. 東 
京大学出版会, 2008, pp161-186

15)ウラジミール・ジャンケレヴィッチ：仲沢紀雄(訳) : 死. みすず書房, 1978

16)エリザベス・キューブラー・ロス：鈴木 晶(訳)：死の 瞬間一死とその過程について. 中央公論社, 2001

17)エリザベス・キューブラー・ロス：川口正吉(訳)：死ぬ 瞬間の子どもたち. 読売新聞社, 1982

18)井手敏郎：3時間目：ブッダの死生学講座. アスペクト 社, 2012

19)キャサリン・M・サンダース：白根美保子(訳)：死別の悲 しみを癒すアドバイスブック：家族を亡くしたあなた へ. 筑摩書房, 2000

20)トーマス・アティッグ: 林大(訳): 死別の悲しみに向き合 う. 大月書店. 1998

21) Drotar D, Baskiewicz A, Irvin N, et al: The adaptation of parents to the birth of an infant with a congenital malformation: A hypothetical model. Pediatrics 1975; 56: 710-717

22) 中田洋二郎：親の障害の認識と受容に関する考察－受 容の段階説と慢性的悲哀. 早稲田心理学年報 $1995 ; 27$ : $83-92$

23)井手敏郎：1時間目：ブッダの死生学講座. アスペクト 社, 2012

24) Damrosch SP, Perry LA: Self-reported adjustment, chronic sorrow, and coping of parents of children with Down syndrome. Nursin Res 1989; 38: 25-30

25)マーシャル・H・クラウス, ジョン・H・ケネル: 竹内 徹, 柏木哲夫, 横尾京子(訳)：親と子のきずな. 医学書院, 1985

26) Breeze ACG, Lees CC, Kumar A, et al: Palliative care for prenatally diagnosed lethal fetal abnormality. Arch Dis Child Fetal Neonatal Ed 2007; 92: F56-58

27）ロバート・A・ニーメヤー：鈴木剛子(訳)：大切なもの
を失ったあなたに一峦失をのりこえるガイド. 春秋社, 2006

28) カール・ベッカー：第 4章 アメリカの死生観教育, その 歴史と意義. 島䄇進, 竹内整一(編); 死生学 [1] 死生学 とは何か. 東京大学出版会, 2008, pp75-104

29)志田久美子, 渡邊岸子：日本における小児の死生観に関 する研究の動向と課題. 新潟大学医学部保健学科紀要 2009; 9: 85-92

30) 仲村照子: 子どもの死の概念. 発達心理研究 1994; 5: $61-71$

31) Speece MW, Brent SB: Children's understanding of death. Child Dev 1984； 55：1671-1686

32)相良ローゼンアマイヤーみはる：子どもの死の感じ方. 小児看護 $2007 ； \mathbf{3 0} ： 1797-1809$

33)相良ローゼンアマイヤーみはる：子どもの死と死後の 世界観: 解釈学的現象学を用いて. 日本看護科学会誌 2004; 24: 12-21

34) 小澤美和, 森本 克, 細矢亮太：小児における同胞の死の 受容について. 日小児科会誌 $2000 ； 104 ： 1197-1206$

35)Hogan NS, DeSantis L: Things that help and hider adolescent sibling bereavement. West J Nur Res 1994; 16: 132-153

36) 芳賀美和, 富田まち子, 菅井加代子: 学童期の子どもが もつ親の死に対する思いー親の死を仮定したアンケー 卜調査からの考察. 第31回成人看護II 2000；84-86(抄録)

37) 安藤正彦ほか: 先天性心疾患患児の精神 - 心理的問題. 高尾篤良, ほか(編): 臨床発達心臓病学改訂 2 版. 中外 医学社, 1997, pp302-311

38) 高尾篤良: 小览心疾患死亡学. 高尾篤良, ほか(編): 臨 床発達心臓病学改訂 3版. 中外医学社, 2001,pp354-356

39)井手敏郎：5時間目：ブッダの死生学講座.アスペクト 社, 2012 
【小児循環器専門医のための総説シリーズ】

\begin{tabular}{|c|c|c|}
\hline \multicolumn{2}{|r|}{ 項立て } & \multirow[t]{2}{*}{ 掲載号 } \\
\hline 1 & 胎児循環生理 & \\
\hline 2 & 心血管系の身体所見 専門医に必要な循環器系理学所見のポイント & \\
\hline \multirow[t]{4}{*}{3} & 薬物について & \\
\hline & 3-1 利尿薬の使い方 & \\
\hline & 3-2 血管拡張剂について & \\
\hline & 3-3 その他 & \\
\hline 4 & 鎮痛・鎮静 & \\
\hline 5 & 肺高血圧の治療戦略 & \\
\hline 6 & 失神について & \\
\hline 7 & 呼吸と循環 & \\
\hline 8 & 超音波検査の原理から応用 & \\
\hline 9 & 心臟カテーテル検査によって得られた結果をどう解釈するか & \\
\hline 10 & 心臓 CT & \\
\hline 11 & 心臓 MRI & \\
\hline 12 & 心臓核医学 & \\
\hline 13 & 運動負荷試験について & \\
\hline \multirow{2}{*}{14} & 先天性心疾患の非手術歴(自然歴) 1 & $30-2$ \\
\hline & 先天性心疾患の非手術歴 (自然歴)2 & $30-3$ \\
\hline 15 & チアノーゼについて & \\
\hline 16 & ペースメーカのすべて & \\
\hline 17 & 小児の心臓移植について & \\
\hline 18 & 体外循環 & \\
\hline 19 & 代表的な手術法 その工夫と問題点 & \\
\hline 20 & 先天性心疾患診療における死生学 & $30-3$ \\
\hline 21 & 小児循環器専門医に必要な統計学 & $30-2$ \\
\hline 22 & 臨床研究と倫理委員会と個人情報保護 & \\
\hline 23 & 川崎病 & \\
\hline 24 & カテーテル治療 & \\
\hline 25 & 不整脈治療 & \\
\hline 26 & 感染性心内膜炎 & \\
\hline 27 & 学校生活, 運動制限 & $30-1$ \\
\hline 28 & 心臓突然死 & \\
\hline
\end{tabular}

